\title{
GEORGIA, TRANSCAUCASUS AND BEYOND
}

GELA

Chief adviser to the president of Georgia on international affairs

The tectonic political shifts that have occurred in the world during the last decade have involved a greater part of the Eurasian continent. A large number of countries underwent radical transformation. Many of them have managed to avoid devastating shocks and bloodshed. In the Caucasus, however, and in Georgia in particular, the process of transformation was extremely painful and at times tragic. Yet, those of us who have survived the disaster are lucky to have observed in the microcosm a rare phenomenon-the collapse of an empire. Equally exciting is watching the nation rise from the ashes, and continue on the road to a better future.

Because of its natural riches, scenic beauty and advantageous location which makes it capable of providing a transit corridor between Europe and Asia, the Caucasus has over the centuries drawn attention and attracted the unremitting interest of major powers. Their encroachments and incessant meddling, that often resulted in pitting peoples, tribes and feudal lords one against another, added to the locally generated woes and, by the seventeenth and eighteenth centuries, life in the area turned into a virtual nightmare. Invasions, forced deportations, mass killings, devastating raids by mountain tribesmen, abductions, slave trade and looting became routine.

It was not until one big power came to dominate the area that things, albeit slowly, began to change. Russia's interest in the Caucasus extends at least four centuries back. It did not, however, materialise until the end of the eighteenth century when a Georgian king asked his co-religionist northern neighbour for protection. It was provided and ultimately led to the abolition of Georgian statehood and virtual annexation of the country. However, it also secured the survival of Georgia's ancient culture, and most importantly, after centuries of isolation, provided via Russia, an access to European ideas and practices. It took Russia over seventy years to pacify the Caucasus, but finally the tsars managed to bring the entire region under their sway and thus alter the course of its historical evolution.

A short period of independence for the Transcaucasian states following World War One and the Bolshevik revolution did witness the re-emergence of some earlier geopolitical patterns, mixed this time with a European element largely attracted by Baku oil and represented mainly by Germany and Great Britain. But the period in question ended abruptly in the spring of 1921. The Red Army crushed the dreams of Transcaucasian independence and the communist dictatorship that followed eventually brought natural development in the area to a virtual standstill. The border to the south was effectively sealed, several nationalities were deported to remote places in Kazakhstan and Siberia, intellectual elites were wiped out, and entrepreneurial activities strictly forbidden. Every field of human effort became highly centralised, whereas local initiative was discouraged and at times, ruthlessly suppressed. Access to international experience was strictly monitored and regulated by bureaucrats in the centre. Understandably, this protracted social experiment that deprived individuals as well as entire nations of their rights and ultimately their ability to adjust through trial and error, resulted in the emergence in the Caucasus and elsewhere of an artificial reality reminiscent of Peter Pan's eternal childhood. Not quite so happy, however, because of its drabness and the inherently violent nature of the regime. But the security of the 'eternal Childhood' seemed to be there and it helped develop mythology that was to play a crucial part first in dismantling the Soviet empire and, later, in securing the failure of a quick transformation.

I am quite certain that many of the myths nurtured by the Caucasian peoples were essentially similar. There must have also been some, however, that reflected the idiosyncrasies of somewhat distinct cultural experiences. I will relate only a few that I have heard voiced in Georgia by average citizens as well as some academics and political leaders. 
1. Nationalism (ethnic rather than state-based) is the cure of all social ills and tensions. The failure of communism to secure ultimate harmony in Georgia was largely due to is emphasis on so-called internationalism.

2. Political unity on serious matters will never be difficult to achieve in post-communist Georgia since the considerations of national interests will invariably outweigh partisan ambitions ("We'll Stand together, tight as a fist!").

3. The introduction of private property will work miracles overnight. Market forces, even unaided, will easily take care of all economic problems.

4. The industrialised world is eagerly waiting in the wings for the opportunity to invest and thus foreign investors will rush onto the scene as soon as communism falls.

5. The international community and NATO in particular, will act promptly to defend Georgia if there is a threat to her sovereignty or territorial integrity.

The above was compounded by several beliefs and attitudes that also developed during the last years of communist rule. The first equated democracy with anarchy and viewed any form of state control as essentially vicious, therefore denouncing every effort to strengthen the governmental institutions since then as attempts to restore a communist dictatorship. Yet another was the belief that anything developed, created or constructed under communist rule, whether an institution, a social pattern, a work of art, or on some occasions even a building, is innately pernicious and criminal and ought to be dealt with accordingly, ie. annihilated. Also public rhetoric abounded in references to history; a highly romanticised image of the remote past was presented as an ideal to be emulated. 'We shall recreate the Georgia of David the Builder,' a twelfth century king. Ironically, at least in terms of energy supply, this prophecy did come true in the following years. Candlelight dinners became a necessity rather than a romantic whim.

This mentality evolved against the highly emotional backdrop created by the traumatic experience of 9 April 1989, when Soviet troops ruthlessly crushed a peaceful demonstration, killing 19 people, most of whom were young women. Understandably, the collective response that followed, abounded in evocations of past grievances and painful historical memories which further fostered emotional reactions as opposed to pragmatic choices. The latter practically became taboo due to the efforts of the newly emerged parvenu politicians who tried to exploit the situation to their advantage. Anyone suggesting a cautious, rational approach with regard to political matters risked being labelled a traitor of the nation.

It was also the time when, owing to the slackening of discipline and the increasing venality in the Russian armed forces, as well as constant assaults on police stations, arms began to spread rapidly. This finally led to the development of what was aptly referred to as a 'Kalashnikov culture', wherein the state ceded its monopoly on violence as all manner of irregular armed formations and criminal groups sprang up and engaged in administering the kind of justice that would suit their own nefarious interests.

The myths raised expectations. The attitudes prescribed behaviour. Emotions ran high. Guns were ubiquitous. Together, they spelled disaster.

The first post-communist government of Georgia, whose president was Zviad Gamsakhurdia, consisted of figures largely responsible for the creation, reinforcement and dissemination of the above mythology, which had helped undermine and implode the previous regime. They proved, however, unable to shift to a realistic vision once the time to gather the stones together came, and continued to act upon false, therefore, destructive premises. It is little wonder, therefore, that the process of disintegration of state and society that had started earlier, now became precipitous and irreversible. Although the new authorities must be credited with declaring Georgia's independence on March 31, 1991, the rest of their 
activities revealed blatant incompetence. Their response to the unfolding new reality was largely neurotic. At times, symbols seemed to matter more to them than substance. Some of the opinions they occasionally voiced exacerbated ethnic tensions and actually helped trigger the fist major internal armed conflict in Georgia. Also, Gamsakhurdia's insulting rhetoric, dictatorial practices and inability to compromise along with his 'amazing gift to turn even his best friends to foes', soon shattered the myth of the inevitable 'tight fist' unity and ultimately led to his being ousted in a bloody uprising in December 1991, effected by his one-time comrades and widely supported by the majority of intellectuals.

Now that the final cord had struck, nothing was left of the state. The economy was a shambles and so was the infrastructure. Law and order were virtually nonexistent. Criminal gangs and armed militias ravaged the countryside, making movement on the roads impossible. People were routinely mugged and held up in the streets. The degree of insecurity of an individual citizen soared to a thitherto unknown high point, whereas the value of human life declined dramatically. One was inevitably reminded of the Hobbesian 'state of nature' wit the 'war of everyone against everyone', and, as a consequence, 'A continual fear and danger of violent death.'

In March 1992, Eduard Shevardnadze returned to Georgia and took charge of the State Council, which was to lead the country into elections scheduled for the autumn of the same year. When asked later how it felt to be back in Georgia, he replied that it was like plunging into boiling pitch. He shared whatever minimal power the council then wielded with most of the political groups that had emerged prior to the collapse of communism, including some that had closely cooperated with the Gamsakhurdia government and, although they had disapproved of the latter's practices, they remained faithful to the basic ideology. Thus, even after the first lessons were learnt, most of the myths were still there and ready to hamper the process of adjustment to the new reality that dawned upon Georgia after the demise of the Soviet Union.

The circumstances under which Georgia was to venture its transformation were by far the worst in the entire area formerly occupied by the USSR. The situation was further aggravated by the armed conflict in Abkhazia and the civil war that followed. Yet, despite the daunting odds, the leadership of the country has never backed down on its commitment to build a democratic state, preserving in the face of enormous difficulties. Special credit should go to the head of state, Eduard Shevardnadze -a statesman of high international profile, whose unflinching courage, infinite patience, extraordinary power of persuasion and the ability to maintain a purpose, have largely determined whatever progress the country has made. Surrounded initially by a bunch of trigger-happy warlords who could and did at will flout the law of the selfsame infant state they were believed to be creating, he had to walk a diplomatic tightrope. Any false move could spark off yet another calamity. A series of terrorist acts that culminated in an attempt to eliminate the head of state were an ominous reminder of the dangers the incipient democracy was facing. Therefore, there may have been at times some tactical compromises, but along the way Shevardnadze never lost the hope or determination to build a Georgia that would be free of criminal networks, dignified, democratic and prosperous.

As early as October 1992, the first internationally monitored elections were held and the legitimate government formed. As soon as the circumstances allowed, radical economic reforms were initiated. Helped all along by the international financial institutions and the major industrial powers, the reform resulted in the stabilisation of the transitional currency, thus creating favourable conditions for the introduction of the new national currency, the lari, in October 1995, which has shown no signs of weakness since. The criminal situation has been effectively dealt with -all irregular armed militias have been disbanded and the streets and roads are safe. The activities of the first multi-party parliament were crowned by the adoption of the constitution -an extraordinary accomplishment given the diversity of opinion across the political spectrum of that body. The latest parliamentary and presidential elections, held on 5 November 1995, were evaluated as free and fair by observers representing the most authoritative international 
organisations. Also, to date, over 7500 enterprises have been privatised and for the first time in the recent years, the GDP is expected to grow.

In his 1992 article entitled 'The Great Transformation', Zbigniew Brzezinsky, laid down several criteria for the three stages that the former communist states have to pass through before they may be viewed as fully transformed. He also set a likely time frame for each stage (1-5, 3-10 and 5-15 years) and grouped the actual countries according to their chances to succeed. Since the article was written at the peak of Georgia's woes, understandably enough, the country was placed in the third category, that is, among those with bleaker prospects, but not altogether hopeless.

However, not only has Georgia completed the first, but has, in fact, moved well into the second stage of transformation just two years afters the reforms were initiated.

Now, let me take you back to the time when the Soviet Union collapsed.

Following the long sleep that blurred the contours of ethnicity and hushed national interests, the awakening peoples of the Caucasus were groping in the twilight for their new or, perhaps, long forgotten identities. As the painful process of adapting to the newly gained freedom evolved, a new set of priorities, some of them potentially destructive, emerged along the way. Irredentism, separatism, territorial claims and counter claims, long repressed in the unconscious by the somewhat sinister Leninist nationalities policy, were now uncomfortably back at work.

The war in Karabakh had already been raging for some time and so had the GeorgianOssetian conflict. In geopolitical terms, at last on the surface, the scene was like the eighteenth century Caucasus with all major powers interested again. However, there were substantial differences.

First was Turkey, a democratic European state that had replaced the Ottoman empire. Scholars of Georgian history have long held the Ottomans responsible for isolating Georgia from European influence in the late Middle Ages, after the fall of Constantinople in 1453. Now it was the new Turkey's turn to do the opposite and it did precisely this. Suffice it to say that, with conflicts raging in Abkhazia and (later on) in Chechnya, Turkey provided the only available overland route to Europe. Very soon, Turkey became Georgia's number one trading partner, and it has remained so until today. At the time of hardship, when Georgia's very survival was at stake, in spite of the pressure exerted by the home-based pro-Abkhaz lobby, Turkey extended credits and humanitarian assistance to its neighbour as well as expressions of commitment to the territorial integrity of a friendly state. Also, Turkey initiated the creation of the Black Sea Economic Co-operation Zone (BSECZ) Ga regional organisation that brings together states that only a few years ago belonged to the opposing ideological camps and military alliances and viewed one another as adversaries. All Transcaucasian states are a part of the BSECZ, which has thus far been chiefly concerned with economic matters, yet is certain to gain a political dimension and concentrate on security issues after a degree of economic integration is achieved.

There was a new Russia -a successor to the states that had dominated the area for two centuries. It still had a military presence in most of the Caucasus and was looking for a modus vivendi compatible with its current interests. It was a country in transition from a totalitarian dictatorship to a market-based, pluralistic democracy. It may have been for this reason that, for the first time in centuries (with the possible exception of the years following the 1917 Revolutions) Russia did not always appear to be a unitary actor, but rather pursued various, at times somewhat inconsistent policies emanating from different institutional sources. The plurality of approaches with regard to the Caucasus and Georgia in particular, became especially apparent during the conflict in Abkhazia when the reactionary neo-imperialist elements entrenched in the Russian political and military 
establishments openly instigated and supported separatists, while the president and his like-minded democratic wing invariably declared their commitment to the inviolability of borders and the territorial integrity of the Georgian state.

Relations with Russia constituted a key element of Georgian policy and are likely to remain so in the future due to historical ties, cultural affinity and the part the northern neighbour is certain to play in shaping the destiny of the region where its language is still widely used as the lingua franca. The years of post-communist development have seen some ambivalence in the attitudes fuelled by radical nationalisation on both sides. However, rational political forces have realised all along that the two nations share a common interest in developing a constructive partnership designed to maintain stability in the Caucasus which, as historical experience and very recent events have demonstrated, is as important for Russia as it is for Georgia.

Georgia has also maintained mutually beneficial ties with the third major regional power, the Islamic Republic of Iran, a successor to the states whose interest in the region and history of relations with the nations populating it extend back to antiquity. At present, the prospects of economic cooperation between the two countries look promising, particularly in the fields of energy, transport and agriculture.

Post-communist Georgia has gone through many hardships and ordeals, but none has been so agonising as the Abkhaz tragedy. It also evinced the emergence of new actors on the Caucasian scene and witnessed some of the old style tampering from the outside. Ethnic Abkhazians, who incidentally made up only 17 per cent of the entire population of the area, first established unfair ethnic-based rule by introducing some ridiculously disproportionate parliamentary quotas. Later, after unleashing an armed conflict against the central authority of the Georgian state in which thousands perished, they forcibly drove away nearly half of the population of the autonomous republic solely because they happened to be Georgian. Thus, they hoped to redress the balance of demographic superiority in their favour and wrench the territory away from Georgia.

Aside from the Cossacks and the reactionary elements in the Russian army, the separatists were helped all along by an obscure political entity calling itself the Confederation of the Mountain Peoples of the Caucasus which, prior to the conflict, had declared the city of Sukhumi its capital, thus stating symbolically its ultimate objectives. Shamil Basaev, whose latter-day activities in the Russian town of Budyonovsk have won him world-wide notoriety, was named the hero of Abkhazia by the separatist regime for the atrocities he committed against the ethnic Georgian population in his role as the commander of the Confederation forces. Ironically, the Confederation has now, mysteriously vanished and has not been heard of since the separatist war, as had been earlier predicted, spilled over the northern slopes of the Caucasian mountains range, which are inhabited by those very peoples whom this ephemeral organisation claimed to represent.

International efforts to bring about a fair settlement in Abkhazia have included over a dozen UN Security Council resolutions, activities by the special envoy of the UN SecretaryGeneral and of the UNHCR, and the constant endeavours of the Russian Federation. A group calling itself Friends of Georgia, composed of the representatives of the United States, Great Britain, Germany, France and Russia, has also done much to encourage a peaceful settlement. However, despite all this and the CIS peace-keeping force and UN observer mission on the ground, no real breakthroughs have occurred so far. Meanwhile, the separatist leaders-perpetrators of ethnic cleansing (as the Final Document of the OSCE Budapest Summit appropriately described their act)-are flagrantly flouting all relevant international documents, including the ones they themselves have signed, and stubbornly denying 250,000 displaced persons their right to return to their homes. Also, they keep rejecting proposals for a fair political settlement, developed by the Georgian, UN and Russian sides, that envisages broad autonomy for Abkhazia within a federal Georgian state. Unrecognised by the world community, they continue to procrastinate secretly hoping for a shift in Russian political attitudes. 
Georgia's relations with her Transcaucasian neighbours have over millennia displayed a lot more friendship and cooperation than antagonism and clashes of interest. In fact, at no point in history has Georgia confronted either its Christian neighbour Armenia or Muslim Azerbaijan, while examples of their joint endeavours abound.

At different times during the last eight centuries, Georgians have sheltered Armenian refugees. Currently, ethnic Armenians make up about nine per cent of the population of Georgia.

A thriving Georgian Community lived in Baku during the original oil boom at the turn of the century. The number of ethnic Georgians currently residing in Azerbaijan is over 15,000. A lot more numerous community of Azeris-over 300,000-presently lives in the territory of Georgia. At the peak of the Karabakh conflict, there were fears that the hostilities could spill over into Georgia and involve local communities of Azeris and Armenians. Fortunately, despite a number of provocations, this did not happen.

At this point, it seems appropriate to state that Georgia has successfully incorporated both the Armenian and the Azeri elements into the texture of its society. It is particularly true of its capital city, Tbilisi which, for several centuries now, has been a home to a multitude of ethnic groups and religious communities. The relaxed ambience of the city that has always been marked by a high degree of ethnic and religious tolerance has encouraged the development of cultures. As a matter of fact, both Azeri and Armenian cultures have flourished in Tbilisi and have produced outstanding works of literature, music and visual art.

Apart from stimulating the advance of individual ethnic cultures, Tbilisi has also acted as a melting pot that synthesised various cultural elements giving rise to a specifically Tbilisi urban culture. I would be remiss if, in this context, I failed to mention

Sayatnova, whose poetry was the ultimate manifestation of the above spirit. Armenian by birth, he was raised in eighteenth century Tbilisi and wrote poetry in three languages, Georgian, Armenian and Azeri. His monument in the old section of the city symbolically represents the unity of the three Transcaucasian nations--a state of affairs highly desirable, but as recent history has demonstrated rather difficult, albeit not impossible to achieve.

Visitors to Georgia, especially those who have been coming at regular intervals, never fail to notice the positive changes--new business emerge daily, expensive foreign cars increase in numbers, smiles are back, people in the streets look a lot more stylish than only a year ago.

However, there is a question that practically all of them ask: is this going to continue? What are the sources of stability that can guarantee the continuation of the reforms?

Let me list our assets:

\section{The Constitution}

The Constitution provides for a strict separation of powers and an effective system of checks and balances. For the new states with a lack of democratic customs and traditions, a legal framework that eliminates any possibility of power abuse is of vital importance. And the Georgian constitution, along with the recent pieces of legislation passed by the parliament, does precisely that. The Constitutional Court, designed to conduct strict judicial reviews, is currently in the making. A law passed recently has introduced the institution of an Ombudsman-a fully independent body responsible for the protection of 
human rights. However, experts estimate that it will take another year to complete the development of an independent judiciary.

\section{President}

Of all the political figures responsible for the latest positive changes in Georgia, by far the most prominent is the president, Eduard Shevardnadze. As recent history has demonstrated, leadership is crucial at a time of transition from the sterile security of communism to the titillating, albeit somewhat frightening, chaos of early laissez-faire capitalism. Shevardnadze's international standing and his absolute commitment to marketbased democracy, are important factors contributing to stability in Georgia, as well as in the entire region. Also, this example is certain to inspire and teach young political leaders who will, some time in the future, take over the reins of power.

\section{Parliament}

One cannot overestimate the importance for stability and progress of smooth interaction between the branches of power. For a country like Georgia which has a huge legislative shortage -thousands of new laws and an equally large number of replacements for the obsolete ones are needed Ğeffective cooperation is crucial. The current 235-seat parliament has proved a great deal more productive than the highly divided old legislature. Today's law-makers seem to concentrate on legislative activities, rather than on partisan skirmishes and personal vendettas. Not only have the new legislators quickly passed a relatively large number of laws, but they have also shown courage and determination in voting for the private ownership of land and a few other sensitive landmark pieces of legislation that are expected to make market reforms irreversible. No other republic has dared to introduce similar legislation. It is universally believed that within its four year term, parliament will be able to fill the existing legislative vacuum and thus develop a procedural infrastructure for democracy and the rule of law in Georgia.

\section{Mentality}

The native romanticism of the first years of independence have given way to rational, pragmatic attitudes. The average Georgian mentality today is essentially immune to radical slogans.

This transformation has occurred due to painful experiences that the nation had to undergo. Also, in this respect, one thing should be borne in mind-Georgians are good learners, because the overwhelming majority are well-educated people. The GDP per head figure in the case of Georgia is quite misleading. With its 100 per cent literacy rate and one of the world's highest ratios of college graduates, Georgia's ability to move forward can by far exceed that of what I would call a classical developing country. motivation is also a factor-the Georgians still clearly remember the higher standard of living they enjoyed and will work hard to achieve it again and go further ahead.

True, initially their education did not effectively shield them from naive political romanticism, but this is easily explainable since as Soviet citizens Georgians had never made political choices or taken any part in the political process for that matter. So, their political sophistication was understandably very low, which made them prey to all manner of pseudo-messiahs.

\section{Middle class psychology}

However incredible it may sound given the unusually low income of the majority of the population, Georgia has a numerous middle class, which is a significant factor in favour of future political stability. It is wrong to define the middle class solely in terms of current incomes. It is a middle class psychology that really matters along with such things as property ownership. The psychology, at least in Georgia, was inherited from the communist 
past and, in fact, was even further bolstered by the privatisation of housing which has turned the majority of the population into property owners. It is little wonder thus that electoral behaviour during the last elections tended to be security oriented and favoured moderate politicians.

\section{Social capital}

Another stabilising factor is what I would describe as survival social capital. That includes unusually close relationships among members of extended families, with branches in both urban and rural areas which allows them to help one another and which serves as an effective mechanism for survival at times of extreme hardship. In recent years, this familiar pattern of living has largely cushioned, or rather absorbed the economic shock and made the continuation of the reforms possible. This pattern also reduces to a minimum the existence of uprooted, 'lumpen' classes of people who otherwise could provide a base for social demagogues.

\section{Vision of a better life}

A coherent vision of the future is necessary for the unity of any society. Although the pace of reforms has been fast, they have not so far produces tangible benefits for the people. Yet, there is an awareness of change and a visceral sense of a better life in the offing, even though many people prefer to grumble about current economic woes. The buzz words are 'oil pipeline' and 'Eurasian transit corridor'. People pin great hopes on those two with regard to generating revenues and bringing prosperity to Georgia.

\section{Oil pipeline and transit corridor}

It is universally predicted that the demand for oil will dramatically increase by the turn of the century as the People's Republic of China and the Asian Tigers continue their economic growth. For this reason, the Caspian Sea oilfields will gain particular importance since they contain the second largest reserves of hydro-carbons in the world. We live in an age of information and therefore, we move our chief commodity-information by simply pushing buttons. The oil, however, is a carry-over from the industrial age and it cannot be simply 'teleported'. So it has to physically flow across territories and is vulnerable to local politics or even crime. Therefore, the industrialised world must have a vested interest in the stability and order of the oil transit areas. The Caucasus is inevitably going to be an important transit route for Caspian hydro-carbons, so, logically speaking, every effort should and will be made by the world community to safeguard order and security in the area.

\section{The Caucasian factor}

In the first years of independence, multi-lateral efforts by the Transcaucasian states to deal with conflicts or other problems practically never occurred. The UN, OSCE and the Russian Federation did most of the facilitating and otherwise helping the peace processes. But now the actual hostilities are over and a new awareness has developed: unless the Caucasian states work jointly, durable peace in the Caucasus can hardly be achieved any time soon. The Georgian president was the first to offer a plan, named 'Peaceful Caucasus', which set forth several principles to be agreed upon by the Caucasian states and their neighbours. Although universal in nature, the principles, when grouped together, show particular relevance to the realities of the Caucasus. I will provide one example: "Communications are to be jointly protected and any disruption or blockage of communication lines should be viewed as an activity directed against the vital interests of the region." Understandably so, since being a transit area, the Transcaucasus will, in the future, largely depend for its revenues on the effective infrastructure that will allow an uninterrupted passage of fuel and cargo. 
In recent months, there have been regular contacts among the leaders of the Caucasian states. Two events deserve special mention. In April in Luxembourg, the European Union signed a partnership and cooperation agreement simultaneously with the three Transcaucasian states, so displaying its confidence in the region. The second event took place even more recently in Kylovodsk. For the first time, the leaders of the Transcaucasian nations and the Russian Federation met to discuss regional problems and were joined by the heads of North Caucasian Republics.

Caucasian cooperation, which is now rapidly gaining momentum, will undoubtedly play an important part along with the efforts of the UN, OSCE and the Russian Federation, in settling existing conflicts. In the future, it is likely to evolve into an effective framework of relationships capable of guaranteeing peace and prosperity in the region.

\section{Georgia's foreign policy}

Last but not least is Georgia's foreign policy, which can be briefly described as pragmatic and based on friendliness. Because we are fully committed to the ideals of democracy and universal human values, we offer our friendship to every nation, regardless its creed and beliefs. Friendship may not sound like a professional term, but so far political scientists have not come up with a better word. Our recent experiences have amply demonstrated that promoting friendship pays, both figuratively and literally. If it were not for the help that came from countries like the US, Germany as well as the European Union and the international financial institutions, we would have hardly survived. The Friends of Georgia group that consists of major European powers plus the US, has rendered support all along by showing commitment to our territorial integrity and seeking ways to settle the conflict in Abkhazia by political means.

Integration is a significant part of our philosophy of international relations. In fact, we envisage the future world order as a unity of integrated regional entities which will ultimately evolve into a single space. With this is mind, Georgia has to spared no effort to get actively involved in the European process and ultimately seeks membership in the European Union. In April, the EU signed a partnership and cooperation agreement with Georgia while, a month later, the Council of Europe granted Georgia a special guest status.

Georgia is currently a part of two regional organisations-the Commonwealth of Independent States (CIS) and the Black Sea Economic Co-operation Zone. Hopefully the two will gradually develop into fully-fledged regional entities capable of providing for the security and well-being of their member states.

In closing, let me emphasise that the upbeat projections contained in this article are based solely on existing trends. New trends may rise any time in any one of the countries mentioned. Yet, temporary aberrations notwithstanding, the general trend in the world is towards market-based democratic development. For this reason, I have little doubt that in the long run most of the odds are in Georgia's favour. 